\title{
Video-Assisted Thoracic Surgery for Patients with Advanced- Stage Non-small Cell Lung Cancer: A Reply
}

\author{
Mark Hennon, MD, Rohit Sahia, MD, Sai Yendamuri, MD, Todd Demmy, MD, \\ Wei Tan, MS, and Chumy Nwogu, MD, PhD
}

Roswell Park Cancer Institute, Buffalo, NY

\section{TO THE EDITORS:}

In response to the letter to the Editor by Cao et al. pertaining to our recent report describing outcomes for video-assisted thoracic surgery (VATS) for a series of patients with advanced-stage non-small cell lung cancer (NSCLC), ${ }^{1}$ we would agree with the comments. The primary intention of our retrospective study was to demonstrate the feasibility and safety of performing VATS resections for patients with advanced-stage NSCLC. Though our conversion rate was higher than what might be expected, this was a select group of cases that normally would have been approached by thoracotomy by many surgeons, even those performing VATS lobectomy for early-stage lung cancer. Expanding inclusion criteria for patients suitable for VATS resection who would be too frail for thoracotomy will expand treatment options for many patients. It is this patient population who stand to benefit most from expanded inclusion criteria for VATS resections.

\section{REFERENCE}

1. Hennon M, Sahai RK, Yendamuri S, et al. Safety of thoracoscopic lobectomy in locally advanced lung cancer. Ann Surg Oncol. 2011;18(13):3732-6.

(C) Society of Surgical Oncology 2017

First Received: 29 October 2017;

Published Online: 27 November 2017

M. Hennon, MD

e-mail: mark.hennon@ roswellpark.org 